\title{
Effects of Interaction Pattern on Students' Interest in Keyboarding in Colleges of Education in South-West, Nigeria
}

\author{
Ogundola C. Modupe
}

\section{ABSTRACT}

This study examined the effects of non-verbal interaction pattern on students' interest in keyboarding in Colleges of Education in Southwest, Nigeria. It adopted quasi-experimental research design of pre-test, posttest non-equivalent control group design. The population for the study was 109 year one students of Office Technology and Management in state owned Colleges of Education in Southwest, Nigeria. Multistage sampling procedure was used to select 35 NCE I students in two of the Colleges offering OTM in Southwest, Nigeria, this comprised of 26 females and 9 males. One research questions and three null hypotheses tested at 0.05 level of significance guided the study. The instrument used for data collection was the Keyboarding Interest Inventory (KII). The KII was developed by the researcher and was subjected to face and content validity by three OTM experts. Cronbach Alpha was used to determine the internal consistency of the KII items. The reliability coefficient computed for the KII was 0.89 . Mean was used to answer the research questions, while t-test was employed to test the hypotheses. It was observed that nonverbal interaction technique was more effective in stimulating students' interest than the conventional method in keyboarding. There was also no significant difference between the interests of students in the experimental (non-verbal) groups based on gender. It was thereafter recommended that NCCE should incorporate non-verbal interaction pattern into the teaching of keyboarding. Lecturers of keyboarding should prepare their classes in such a way that students are allowed ample opportunity to critically think, interact freely with one another, discourage students' passiveness and improve performance in pair and group activities among other recommendations.

Keywords: keyboarding, non-verbal interaction, office technology and management students.

Published Online: January 25, 2021

\section{ISSN: $2736-4534$}

DOI: $10.24018 /$ ejedu.2021.2.1.26

\section{M. Ogundola}

Bamidele Olumilua University of Education, Science and Technology, Ekiti State, NIGERIA.

(e-mail: ogundolacmodupe $@_{\text {gmail.com) }}$

*Corresponding Author

\section{INTRODUCTION}

Business Education is the type of education that equips the individual with knowledge, occupational skills and competencies needed to enter into business world or teaching profession in order to earn a living. It aimed at equipping recipients with knowledge and saleable skills that will enable them fit into the world of work. Business education focuses on skills and knowledge acquisition for the recipients with a view to enhancing their capability for self-employment. In the view of Nwokike, Ezeabii and Jim (2018), business education programme is concerned with teaching the skills, attitudes and knowledge necessary for a successful carrier in office and business world. Business education is an aspect of vocational education offered in universities' faculties of education and colleges of education in Nigeria.
Colleges of Education are teacher training institutions established to train middle level manpower. The programmes in Colleges of Education are made to run for a period of three years. In order to achieve uniform and effective manpower training, a national curriculum is adopted in all the Colleges of Education programmes (OTM inclusive) accredited by the National Commission for Colleges of Education (NCCE), the main body saddled with the responsibility of controlling programmes and activities of the colleges. Common options of business education include accounting, marketing and office technology and management (OTM).

Office Technology and Management (OTM), is a nomenclature that was used to replace the old Secretarial Studies Curriculum which was found grossly inadequate for the demand of the employers of labour in the information and communication technology era. Amiaya (2015) opined that changes in work processes and business 
organizations as well as the model of transmission and exchange of information in the globalized economy call for transformation in the teaching and learning process in office technology and management (OTM) to reflect the emphasis in the use of Information and Communication Technology (ICT). OTM program, being a skill acquiring discipline, remains a relevant channel for the transmission of the appropriate ICT skills and knowledge in order to make its graduates ICT savvy to embrace globalization and meet the demands of today's work place (Chigbuson, Durtur and Nimfel, 2016).

Courses that make up OTM include Shorthand, Office Practice, Business Communication and Keyboarding. As a result of fast developing and changing technology, keyboarding has become an invaluable skill to students and those in the workplace. Technological progress and development have not only resulted in information being made available faster and easier, but it has put more pressure on secretaries whose work now mostly depends on the use of computer to develop very high keyboarding skill. It has, thus become a necessity for OTM students to be trained in the proper use of the computer keyboard if they are to function optimally in their workplace after graduation.

Keyboarding skill, according to Elsie, Jan and Elsa (2006) is a motor skill, and the ability of learners to key in information into the memory of the computer with the minimum effort and energy use. Keyboarding could be on a typewriter, computer or other electronic data processing equipment. Keyboarding involves the manipulation of keys on a standard keyboard with the emphasis on the typed copy or output. Akhigbe (2015) posited that keyboarding is a skill that allows students to interact efficiently with electronic input devices either for educational purpose, personal usage or future employment.

Keyboarding is normally taken at the first two of the six semesters which students are expected to spend for the programme. At the second year, the course changes to word-processing which is an application of the keyboarding learnt during the first year of the study. By this, observation reveals that the way and manner in which students manipulate the keys do not show adequate possession of dexterity for the attainment of the objective of the course.

In order to achieve the objective of production of competent OTM specialists, government at both the federal and state levels expended huge amount of money on the procurement of equipment for use at colleges. In the same vein, such efforts like curriculum review, policy shift, re-training, and production of highly qualified lecturers by the government to ensure qualitative education at the Colleges of Education and bring about high quality products both in academics and for employment seems not to have yielded much dividend (Ogundola, Agboola and Ogunmilade, 2020). This might be due to some factors which may include inadequacy in the curriculum content, poor implementation of the curriculum, qualification and quality of lecturers and poor technique of instructional delivery.

One probable cause of poor performances and lose of interest in Keyboarding by OTM students according to
Ezeani and Ogundola (2016) may include inappropriate teaching strategy adopted in teaching the students. This assertion corroborated the Federal Government Reports (2013) on vocational education which revealed that students in Technical Colleges are always put-off or not interested in vocational education because of the unmotivating and unchallenging approach used by their teachers. Keyboarding is an integral part of Office Technology and Management education, in order to facilitate teaching and learning; interest of the students is a relevant factor.

An interactive teaching strategy may arouse the interest of students. As long as the students become interested in learning, they will show enthusiasm to the activities to participate in and be active to learn and explore, improve the efficiency and develop new abilities (Yu Zhao, 2014). Interest is a persisting tendency to pay attention and enjoy some activities. Interest has been viewed by Judith, Jessi and Stacy (2016) as a powerful motivational process that energizes learning, guides academic and career trajectories. Osuafor (2012) described interest as that attraction which forces or compels a student to respond to a particular stimulus. Interest does not come as a result of force, it is as a result of an individual's eagerness to learn. Therefore, interest is an affective behaviour that can be aroused and sustained in teaching and learning through appropriate teaching strategy. Students' performance in any learning activity is sustained by the active involvement of the learner in all aspects of the learning process. Uduogie (2001) and Ngwoke (2004) emphasized that unless the lecturer stimulates students' interest in learning, students' achievement will be minimal, hence, it is essential that business education lecturers use teaching strategy that ensures students' active involvement in learning to stimulate interest and thus improve performance.

The communication between the lecturer and the students is an essential part of teaching and learning process and this communication refers to the interaction among key actors in the teaching-learning process, i.e.(students and teachers). Nrungu, Nyagah and Mugambi (2019) explained that through the process of interaction, learners are actively involved, contribute in the process of learning and build knowledge from what they already have, leading to meaningful learning. Classroom interaction, being an essential part of the teaching-learning process referred to various activities that take place between the lecturer and the learner, the lecturer and the materials, the learner and other learners as well as the learners and the materials. Thus, positive classroom interaction engenders positive attitude. It enhances the willingness and the capacity of the students to benefit substantially from the teaching-learning process. Olatiilu (2016) identified common classroom interaction technique to include classroom conversation, question and answer, role-playing, verbal and non-verbal interaction.

Verbal interaction technique is a lecturer-studentmaterial interaction that entails lecturers giving verbal guidance as the students carry out the activities given to them. Thus lecturers are moderately active in this pattern. The Non-verbal interaction (NVI) technique is a technique 
indicative of students very active and lecturer less active, it is a student-centred learning. Non-verbal interaction is mostly expressed through non-linguistic means, with minimal verbal guidance by the lecturer. In a non-verbal interaction class, students are expected to follow precise lecturer's written instruction to complete a hands-onactivity by the provision of a procedural manual in form of task elements.

Non-Verbal Interaction creates a learning environment conducive to learning and promotes the highest levels of motivation, learning, and achievement for all learners (Ahmed, 2013). Non-Verbal Interaction instruction is most suitable for the more autonomous, and more selfdirected learners who not only participate in what, how, and when to learn, but also construct their own learning experiences.

\section{PURPOSE OF THE STUDY}

The major purpose of the study is to examine the effects of non- verbal interaction pattern on the interest of students' in Keyboarding in Colleges of Education in South West, Nigeria. Specifically, the study sought to determine:

1) OTM students' interest in keyboarding when exposed to Non-Verbal Interaction (NVI) technique;

2) gender on the interest of OTM students taught keyboarding when exposed to Non-Verbal Interaction (NVI) technique.

\section{RESEARCH QUESTION}

The below research question was raised to guide the study:

1) What is the effect of non-verbal interaction technique on OTM students' interest in Keyboarding in Colleges of Education in South West Nigeria?

\section{RESEARCH HYPOTHESES}

The following null hypotheses were formulated to guide the study and were tested at 0.05 level of significance.

1) There is no significant difference in the pretest interest mean scores of OTM students exposed to non-verbal interaction technique and students exposed to conventional method when taught Keyboarding.

2) There is no significant difference in the post test interest mean scores of OTM students exposed to nonverbal interaction technique and students exposed to conventional method when taught Keyboarding.

3) There is no significant difference in the interest of OTM students exposed to non-verbal interaction technique based on gender after treatment.

\section{METHODOLOGY}

A quasi-experimental design with a pre-test and posttest design was adopted. In this study, there was one experimental group and a control group. The experimental group was made up of students in the nonverbal group while the second group was made up of the control group. The study was carried out in South-West Nigeria. The population for this study was all One hundred and nine (109) NCE I OTM students in Colleges of Education in South West, Nigeria. There are eight states owned Colleges of Education offering Office Technology and Management in South West, Nigeria.

The sample size for this study consisted of all 35 NCE I students in two of the Colleges of Education running OTM programme in Business Education in South West, Nigeria (College of Education, Ikere-Ekiti and Emmanuel Alayande College of Education, Oyo, Oyo State). These comprised 26 female and 9 male students. The simple random sampling technique was adopted for randomly assigning the two Colleges of Education identified above to experimental and control groups in the study.

\section{INSTRUMENTS FOR DATA COLLECTION}

The instrument used for data collection in this study was the Keyboarding Interest Inventory (KII) which was developed by the researcher for the purpose of testing students' interest in keyboarding. Section A sought information on the bio-data of the respondents while section B contains 25 items designed to elicit information on the interest of students toward keyboarding. The items were based on four-point modified Likert scale of Strongly Agree (SA), Agree (A), Disagree (D) and Strongly Disagree (SD). Each respondent was requested to tick the appropriate option. The responses were collated and scored for data collection.

The validity of the Keyboarding Interest Inventory (KII) was ensured by conducting face and content validity on the developed instrument. A total of thirty items about keyboarding was initially generated. The face, content and construct validity of the instrument was established by ensuring that it measured the appropriate interest traits it was developed to measure. It was also given to three OTM experts for necessary corrections and suggestions. The experts were specifically requested to examine the KII items with respect to the extent to which the statements in the KII assess students' interest in the units of study. Following the face and content validity, the items were reviewed based on their comments, and twenty-five statement items were finally selected to constitute the KII.

Cronbach Alpha was used to determine the internal consistency of the Keyboarding Interest Inventory (KII) items. The KII instrument was administered on 15 year I OTM students in a college of Education which was not part of the study area. The reliability coefficient computed for the Keyboarding Interest Inventory (KII) was found to be 0.89 . This formula was considered appropriate due to the fact that composite scores of the students on the instrument were required and also that the formula is applicable to items that are not dichotomously scored such as the KII.

\section{EXPERIMENTAL PROCEDURE}

The study was conducted in three phases: The first phase was the pre-test stage. It was the phase in which the KII was administered on the subjects in both the experimental and control groups. This phase of the study was done in the first week of the experiment this exercise provided baseline data on interest inventory. 
The second phase which is the experimental or test phase featured the teaching of the experimental group with the developed NVI teaching method lesson plan, while at the same time, the conventional group was taught the same topics using the usual teaching methods and lesson plan as developed by the respective teachers handling the classes. Keyboarding lecturers in the experimental group used the researchers' developed lesson plans to teach. During the treatment, the control group received no new treatment.

In all, four major topics were covered in this study, these includes Speed and Accuracy, Business Letter, Memorandum and Tabulation. The treatment for this research lasted for five weeks, while each lesson lasted for 2 hours (double periods).

The third phase was the post-test phase. A post-test was administered on both groups using the KII instrument by the Keyboarding lecturers and their assistants after the treatment. The exercise provided post-test data for the dependent variable (interest) after the treatment.

The data obtained from the students' were analysed by the use of mean to answer research questions and the t-test for testing the hypotheses.

\section{PRESENTATION AND ANALYSIS OF DATA}

\section{A. Research Question}

What is the effect of non-verbal interaction technique on Colleges of Education OTM students' interest in Keyboarding in South West Nigeria.

TABLE I: MEAN SCORES OF INTEREST INVENTORY OF OTM STUDENTS TAUGHT WITH NON-VERBAL INTERACTION AND CONVENTIONAL METHOD

\begin{tabular}{lcccccc}
\hline \hline & & \multicolumn{2}{c}{ Pretest } & \multicolumn{2}{c}{ Posttest } & \multirow{2}{*}{ Mean } \\
Methods & $\mathrm{N}$ & Mean & SD & Mean & SD & Difference \\
\hline Non-verbal & & & & & & \\
Interaction & 19 & 29.98 & 7.61 & 76.19 & 7.42 & 46.21 \\
Conventional & 16 & 30.69 & 7.28 & 53.69 & 7.07 & 23.00 \\
\hline \hline
\end{tabular}

Table I indicates that students exposed to non-verbal pattern teaching strategy and conventional method had mean scores of 29.98 and 30.69 respectively prior to treatment in the interest inventory; hence, the groups were homogeneous at the beginning of the experiment. On exposure to treatment, students taught with non-verbal technique strategy had higher mean score of 76.19 while those in conventional group had 53.69. This implies that the use of non-verbal interaction pattern is more effective in improving College of Education OTM students' performance in keyboarding than the conventional method. This is further depicted in figure I.

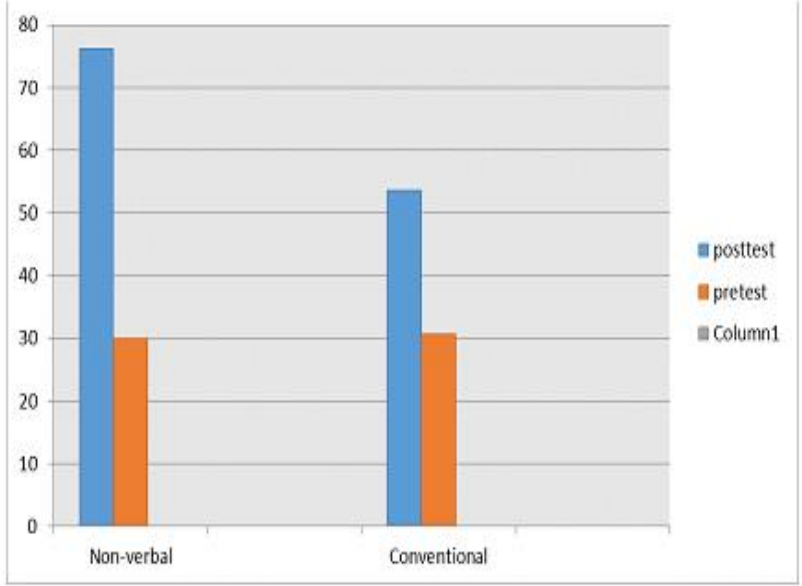

Bar Chart

Figure I: Bar-chart representing interest mean scores of College of Education OTM students, before and after exposure to nonverbal interaction pattern and conventional teaching method.

Ho1: There is no significant difference in the pretest interest mean scores of OTM students exposed to non-verbal interaction technique and students exposed to conventional method when taught Keyboarding

TABLE II: T-TEST ANALYSIS OF PRETEST MEAN INTEREST SCORES OF STUDENTS EXPOSED TO EXPERIMENTAL AND CONTROL CONDITIONS.

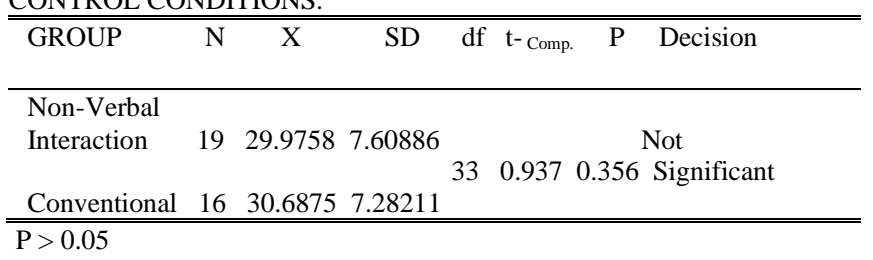

Table II shows that $(\mathrm{t}(33)=0.937, \mathrm{p}>0.05)$. The null hypothesis is accepted. This implies that, there is no significant difference in the pretest interest inventory scores of OTM students exposed to non-verbal interaction technique and students exposed to conventional method.

$\mathrm{HO} 2$ : There is no significant difference in the post test interest inventory mean scores of OTM students exposed to non-verbal interaction technique and students exposed to conventional method when taught Keyboarding

TABLE III: T-TEST ANALYSIS OF POSTTEST MEAN INTEREST SCORES OF STUDENTS EXPOSED TO EXPERIMENTAL AND CONTROL CONDITION.

\begin{tabular}{lccccccc}
\hline \hline GROUP & $\mathrm{N}$ & $\mathrm{X}$ & $\mathrm{SD}$ & $\mathrm{df}$ & $\mathrm{t}-$ Comp. & $\mathrm{P}$ & Decision \\
\hline $\begin{array}{l}\text { Non-Verbal } \\
\text { Interaction }\end{array}$ & 19 & 76.1863 & 7.41896 & & & & \\
& & & & 33 & 8.494 & 0.000 & Significant \\
Conventional & 16 & 53.6875 & 7.06842 & & & & \\
\hline P $>0.05$ & & & & & & &
\end{tabular}

Table III shows that $(\mathrm{t}(33)=8.494, \mathrm{p}<0.05)$. The null hypothesis is rejected. This implies that, there is a significant difference in the posttest interest inventory means scores of OTM students exposed to non-verbal interaction technique and students exposed to conventional method. 
HO3: There is no significant gender difference in the interest of OTM students exposed to non-verbal interaction technique after treatment

In order to test the hypothesis, students' scores in keyboarding interest inventory in post-test in the experimental (non-verbal interaction) group were sorted by gender and computed using t-test. The result is presented in table 4 .

TABLE IV: T-TEST ANALYSIS OF POSTTEST MEAN INTEREST SCORE OF MALE AND FEMALE STUDENTS EXPOSED TO EXPERIMENTAL CONDITION.

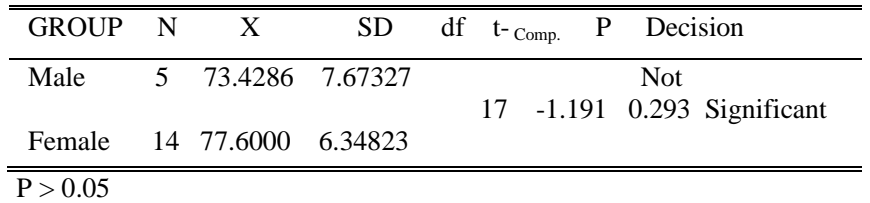

Table IV shows that $(\mathrm{t}(17)=-1.191, \mathrm{p}>0.05)$. The null hypothesis was not rejected. This implies that, there is no significant difference in the mean interest score of male and female students exposed to non-verbal interaction technique.

\section{DISCUSSION OF FINDINGS}

The data presented in Table 1 provided answer to research question one. Findings revealed that non-verbal interaction was more effective in improving students' interest in Keyboarding. This finding indicates that nonverbal interaction technique is more effective in stimulating students' interest in keyboarding than the conventional method. The t-test analysis of the treatments effects on interest presented in Table 3 showed that there was a significant difference between non-verbal interaction and conventional group on students' interest. Thus the difference between the two variables in stimulating students' interest was statistically significant. This implies that the observed differences noticed in table 1 as to the superiority of non-verbal interaction technique as a better teaching strategy than the conventional method in improving students interest is not due to chance. Nonverbal interaction technique is a more student centred and more practical oriented teaching technique whereby students are involved in hands-on-activity. This, according to Holstermann, Grube and Bogehole (2010) in their study titled "Hands-on Activities and Their Influence on Students' Interest", observed that when students are given opportunity to think critically, it makes them have confidence in themselves thus stimulating the will to accomplish a given task without being forced. Hence their interest was highly stimulated when compared to conventional method. The findings of the study also corroborated the work of Akhigbe (2015) who observed that students who struggled to work without the help or supervision of a lecturer showed positive typing behaviours, interest and growth toward independent learning.

Furthermore, another salient finding from this study is that no disparity exists in the interest of OTM students taught keyboarding with non-verbal interaction technique. Student t-test analysis was used, test for significant difference between the main effects of gender on students' interest in keyboarding as presented in Table 4 showed that there was no significant difference between the main effect of gender (male and female) on students' interest in nonverbal interaction technique. This implies that the effectiveness of non-verbal interaction technique on students' interest in non-verbal interaction technique is independent of gender.

Interestingly, providing of opportunities to interact with course material through the use of appropriate computer software, application, tools and equipment cooperatively tends to change the course from a competitive endeavour to one that is more student-centered, and focused on the construction of knowledge in the students (Brewer, 2003). Hence, one means of constructing knowledge is to create meaning by doing. The obvious implication of the use of appropriate computer software applications and equipment therefore, is to facilitate students' interaction with the learning environment. This will help to sustain students' interest which increases the strength of ego-involvement of the learners and which does not allow the learners to be distracted by trivial extraneous events in the perceptual environment.

\section{CONCLUSION}

Based on the findings of this study, it could be concluded that the two groups (non-verbal interaction technique and conventional method) were homogenous at the commencement of the experiment.

Based on the findings of this study, it could be concluded that the interest of OTM students in keyboarding were low before the treatment. This was discovered in the study as a result of the usual conventional method of teaching and learning used by lecturers in Colleges of Education which is lecturer-centred.

There were improvements on the interest of students after the treatment. The study therefore concluded that the use of non-verbal interaction was responsible for these improvements.

\section{RECOMMENDATIONS}

Based on the findings of this study, the following recommendations were made:

1) Lecturers of Keyboarding should be encouraged to adopt the use of non-verbal interaction teaching technique to the teaching of Keyboarding.

2) Lecturers of keyboarding should prepare their classes in such a way that students are allowed ample opportunity to critically think, interact freely with one another through non-verbal interaction teaching technique class so as to improve their psychomotor achievement.

3) The National Commission for Colleges of Education (NCCE) should consider review of curriculum for keyboarding with a view to incorporating non-verbal interaction technique into the teaching of keyboarding. 


\section{ACKNOWLEDGMENT}

Ogundola C. Modupe appreciates the students of Office Technology and Management Education used for this study for their support and patience during the course of administration of the instrument.

\section{REFERENCES}

O. J. Akhigbe, "Effects of computer-assisted programmed instruction and demonstration method on achievement of national diploma students in keyboarding in south-south, Nigeria," Unpublished Ph.D dissertation, Faculty of Education, Ekiti State Univ., AdoEkiti, 2015.

O.I. Olatiilu, "Effect of classroom interaction patterns on the academic performance of Ekiti State Public Secondary School Students in Chemistry," Unpublished M.Ed. thesis, Faculty of Education, Ekiti State Univ., Ado-Ekiti, 2016.

A. M. Osuafor, " Effects of field trip and role playing on pupils achievement and interest in environmental concepts in primary science," Unpublished Ph.D dissertation, Univ. of Nigeria, Nsukka, 2012

A. O. Amiaya. (2015). Information and Communication Technology challenges and Strategies among Office Technology and Management Educators in Nigerian Polytechnics," International Journal of Education and Practice, Conscientia Beam, 3(3). pp. 156-167. https://ideas.repec.org/a/pkp/ijoeap/2015p156-167.html

C. Brewer. (2003). Computer in the classroom: How information technology can improve conservation education. http://www.ibscre.dbs.ur.nt.edu/publication/BrewerconBioarticle. $p d f$

A. J. Chighuson, S. L. Durtur S. L. and T. Nimfel, (2016). Perception of teachers and students on factors affecting the teaching and learning of information and communication technology courses in the polytechnics. Nigerian Journal of Business Education (NIGJBED). 3(2). pp. 216-226 http://www.nigjbed.com.ng

L. Elsie, M. Jan and M. Elsa. (2006). The relationship between keyboarding skills and self-regulated learning. South African Journal of Education. 26(2). pp. 281-293. https://files.eric.ed.gov/fulltext/EJ1150417.pdf

N. S. Ezeani, and C. M. Ogundola. (2016). Business education in Nigeria : past, present and future in the $21^{\text {st }}$ century. Nigerian Journal of Business Education. , 3(1). pp. 17-33. http://www.nigjbed.com.ng/index.php/nigjbed/article/view/4

Federal Republic of Nigeria . (2013). National Policy on Education. 6th ed, NERDC Press. https://issuu.com/esspin/docs/national_policy_on_education

N. Holstermann, D. Grube, and S. Bogeholz. (2010). Hands-on activities and their influence on students' interest. Research in Science Education. 40(5). https://www.researchgate.net/publication/227294563_Hands on_Activities_and_Their_Influence_on_Students'_Interest

M. H. Judith, L. S. Jessi and J. P. Stacy. (2016). Interest Matters : The importance of promoting interest in education. Policy Insights Behavioural Brain Sciences. 3(2). 220-227. www.ncbi.nlm.nih.gov/pmc/articles/PMC5839644/

Ngwoke, D. U. (2004). School learning theories and applications. Enugu: Magnet Business https://oer.unn.edu.ng/read/school-learning-theory-andapplications?rdr=1

M. N. Nrungu, G. Nyagah and M. Mugambi (2019). Learner-teacher non-verbal interaction effect on academic achievement of learners in chemistry. African Educational Research Journal. 7 (2). pp 88-96. https://files.eric.ed.gov/fulltext/EJ1221237.pdf

F. O. Nwokike, I. C. Ezeabii and E.U. Jim. (2018). Business education : an indispensable tool for achieving sustainable development in the South-East States of Nigeria. European Centre for Research Training and Development UK. British Journal of Education. 6(1). pp. 19-27. www.eajournals.org

I. P. Ogundola, G. B. Agboola and J.O. Ogunmilade. (2020). Gender differences in achievement, interest and retention of students' exposed to fabrication and welding engineering craft practice through cognitive apprenticeship instructional technique in Nigeria,. Educational Research and Review. Academic Journals, Kenya. 15(4). pp. 194-202,
I. Uduogie. (2001). Role of teachers in motivating students' interest in science and mathematics. International Institute for Capacity Building in Africa. 3(1). pp 1-5. www.unesdoc.unesco.org/ark:/48223/pf0000231596

Ogundola Cecilia Modupe is a Lecturer in the Department of Busines Education, School of Social Sciences, Faculty of Education, Bamidele

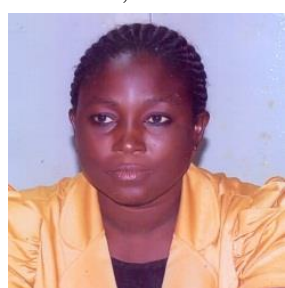
Olumilua University of Education, Science and Technology, Ikere-Ekiti, Nigeria. She completed her second degree in Business Education at Ekiti State University, AdoEkiti. Nigeria, with a specialization in Office Technology and Management Education. She has published in national conference proceedings as well as in scientific journals. 